\title{
Distance Learning as a Resilience Strategy during Covid-19: An Analysis of the Italian Context
}

\author{
Andrea Appolloni ${ }^{1,2, * \mathbb{C}}$, Nathalie Colasanti ${ }^{1}$, Chiara Fantauzzi ${ }^{1}$, Gloria Fiorani ${ }^{1}$ and Rocco Frondizi ${ }^{1} \mathbb{C}$ \\ 1 Department of Management and Law, University of Rome Tor Vergata, 00133 Rome, Italy; \\ nathalie.colasanti@uniroma2.it (N.C.); chiara.fantauzzi@uniroma2.it (C.F.); gloria.fiorani@uniroma2.it (G.F.); \\ rocco.frondizi@uniroma2.it (R.F.) \\ 2 Institute for Research on Innovation and Services for Development (IRISS), National Research Council (CNR), \\ 80134 Naples, Italy \\ * Correspondence: andrea.appolloni@uniroma2.it
}

Citation: Appolloni, A.; Colasanti, N.; Fantauzzi, C.; Fiorani, G.; Frondizi, R. Distance Learning as a Resilience Strategy during Covid-19: An Analysis of the Italian Context. Sustainability 2021, 13, 1388. https:// doi.org/10.3390/su13031388

Academic Editor: Idiano D'Adamo

Received: 30 December 2020

Accepted: 25 January 2021

Published: 29 January 2021

Publisher's Note: MDPI stays neutral with regard to jurisdictional claims in published maps and institutional affiliations.

Copyright: (C) 2021 by the authors. Licensee MDPI, Basel, Switzerland. This article is an open access article distributed under the terms and conditions of the Creative Commons Attribution (CC BY) license (https:// creativecommons.org/licenses/by/ $4.0 /)$.

\begin{abstract}
The purpose of this paper is to analyze the strategic model of distance learning adopted by Italian higher education, showing how the health emergency due to Covid-19 has transformed it from an "optional" for traditional universities to the only means to ensure public health protection and continuity in education programs. Comparing two situations (before and during the pandemic), the aim is to identify best practices that, even after the end of the emergency, can be adopted by Italian higher education institutions to boost their digital supply and compete in an international context. After a general context analysis, aimed to underline benefits and risks connected to the development of distance learning, the case of the Italian higher education system has been analyzed. Data were collected through a documentary analysis, looking at what Italian higher education institutions disclosed through their official websites and documents: every form of communication about digital strategy was taken into account. Then, they were analyzed qualitatively, in order to individuate which platforms have been combined to ensure quality in education provided. Research findings demonstrate the resilience of the Italian higher education, able to react and to re-organize itself in only one week: the results of the pandemic may be a stronger university, able to combine quality in education with the potential of technological devices and to compete at the international level. Distance learning represents a complex field, still characterized by separated understandings and in a context where limited attention has been dedicated to its development for what concerns the Italian context, the choice to examine it represents the originality of this paper.
\end{abstract}

Keywords: higher education; digitalization; distance learning; Covid-19 outbreak; resilience

\section{Introduction}

Among different transformations that took place during the last years, digitalization has changed the ways to work and to do things, and also to teach and learn [1]. According to Westerman et al. [2], digitalization can be defined as the use of different digital devices to change existing business models, improving services and facilitating trade and activities. Therefore, in a context where education is seen as one of the solutions to many of today's problems, such as unemployment, world peace, and poverty, the aim of universities is not just to deliver education, but to become more digital learning institutions updating their strategy in order to meet the new requests and expectations of students and other stakeholders.

According to Drucker [3], now and hereafter, knowledge represents the key to success, and higher education institutions have to satisfy the needs of their students even after the end of their educational path in order to ensure continuously new and updated knowledge during the course of their career $[4,5]$.

In a globalized society, oriented to international competition and characterized by the spread of internet and other technology devices [6], a growing number of individuals 
has been inspired to ask for further new learning opportunities, available anywhere and anytime, without requiring physical presence in universities.

The answer has been the rise of distance learning, which can be seen as an evolution of lifelong learning, through the appearance of online universities, able to offer distance courses by exploiting new communication devices and to deliver academic qualifications recognized by the State in which they operate. Given the rise of these online universities, perceived as new competitors by the traditional ones, higher education institutions have been forced to update their strategy and modify their supply.

The real value of digitalization and distance learning has been underlined during the Covid-19 emergency: it is during such occasions that distance learning, previously perceived as a simple answer provided by traditional universities to the recent rise of the online ones, has become the only means to perform education and training paths for all levels and all kinds of institution, at the same time ensuring health protection.

More precisely, it is during the health emergency that distance learning assumed the form of emergency remote education (ERE), allowing students, teachers, and lecturers to continue their learning and teaching activities $[7,8]$.

On the basis of these considerations, the aim of this work is to investigate the strategic model of distance learning adopted by Italian higher education, showing how the pandemic has accelerated its growth and evolution. The aim is to present emergency remote education as a sustainable and resilience strategy for higher education, in order to support the rebirth after Covid-19 [9]. Indeed, if according to Gallagher et al. [10], sustainability is based on the triple bottom line-people, profit, and planet-it is clear that today distance learning represents the instrument to foster its social dimension. Furthermore, distance learning could represent a way to foster the environmental dimension of sustainability: using sharing platforms, it allows to create value in a circular way, building new communities and providing students with more affordable and convenient access to education, the first step towards the achievement of green campuses [11,12].

Identifying specific best practices that, even after the end of the emergency, can be adopted by all Italian higher education institutions, the aim is to answer the following research questions: how has the Italian higher education reacted to Covid-19 outbreak? Which lessons can be learned from the pandemic experience?

Findings suggest that before the pandemic emergency, Italian higher education institutions started to open themselves to such innovation, showing a huge delay if compared to other international universities.

The pandemic has turned upside down all the education systems over the world, including the Italian one, forcing all institutions to interrupt their traditional activities and then to experiment emergency remote education in order to ensure continuity for all education programs.

So the methodology of case study has been adopted, with the Italian higher education system representing the object of the analysis. It has been chosen not because it is extreme or unusual, but because researchers are members of it, providing additional longitudinal elements from their personal experience. The Italian case has never distinguished itself for its capacity to evolve and to welcome digitalization, but the velocity in which it has translated to online justifies the originality of the paper. Furthermore, it has been analyzed in a very extraordinary time (Covid-19 outbreak).

The paper is the output of the first phase of our research, since it analyzes distance learning as emergency remote education, so as an instrument adopted to provide answers in a time of emergency. On the basis of evidence emerged, the second phase of the research will point out the evolution of distance learning in Italian universities, analyzing it as a usual and structured practice.

The paper is structured as follows. Section 2 analyzes the development of digitalization in higher education, with a specific focus on distance learning, underlining the main features and limits of such a new way to provide education. 
Section 3 is dedicated to explaining the methodology adopted to collect and analyze data, and findings are presented in Section 4, with the aim of pointing out the model of distance learning adopted in Italy, before and during the health emergency; a brief introduction will be dedicated to present the measures enacted by the Italian government with the aim of ensuring public safety and education provision. Discussions are presented in Section 5 and preliminary conclusions in the final one, hypothesizing the future of distance learning in the Italian context.

\section{Digitalization in Higher Education: The Development of Distance Learning}

Today, digitalization is everywhere around the world, changing operations within organizations and enabling far-reaching social and political changes [1]. It represents a transformation process, which requires the implementation of a specific strategy, aimed to better satisfy customers' wishes and preferences and, sometimes, able to ensure competitive advantage [13].

Digitalization represents one of the main challenges for all kinds of institutions [14], including universities, that have been called to become more digital and to assist students in coping and leading such transitions [1]. Indeed, in a context characterized by the spread of the internet and other technology devices, the main need for higher education is not just for capturing knowledge, but also for exploiting new technologies in order to "teach to learn" and "learn to learn" independently [15]. The market has become global everywhere, and higher education institutions have started to compete globally: it is in such a context that they have to leverage new digital potential to benefit in the digital era [16,17]. As a consequence, universities, previously seen as "ivory towers" [18], have been called to update their strategy, in order to ensure accessible and affordable learning opportunities for all [19], adapting themselves to the needs of individuals and providing education in a variety of settings and forms, even outside of the school system [20]. They have been called to develop a new e-learning strategy, with the aim to provide answers to the growing demand for new and different learning experiences [21], fostering the development of distance learning [22].

In this sense, the development of distance learning turns out to be strictly connected with the diffusion of new technologies, but, in reality, it has arisen through the introduction of printers and printed books, less expensive and more accessible for a wider audience [23]. Therefore, the evolution of distance learning can be divided into three sections: the first one was characterized by the use of material printed exclusively for students, the second one by the use of television in order to deliver courses, and the last one dominated by internet and other technologies. During the last section (1994-2000), universities have started to perform e-learning or blended learning experiences, and in 2008 they developed "massive open online courses" (MOOCs) in order to offer a possible solution to a rapidly increasing need for education worldwide [24].

Therefore, in this sense, the development of distance learning can be seen as the direct consequence of digitalization in higher education, enabling both the societies and education organizations to create new opportunities to grow, improve, change, and renew themselves [25].

Of course, digitalization brings several opportunities, increasing interactions and collaborations with stakeholders [26], but, at the same time, it could be characterized by negative aspects, such as the risk of losing customers who are used to traditional services [27], and when problems occur, ordinary employees are unable to solve them, requiring the involvement of IT experts (an additional cost for organizations) [28].

Likewise, according to Veletsianos and Kimmons [29], distance education solutions could be analyzed in terms of strengths and weaknesses: while they offer open access, open education, open teaching, and network participation, on the other hand, they are associated with the problem of low completion rates, poor quality assurance, and lack of adequate assessment tools. Furthermore, high workloads, challenging course content, lack of time, lack of pressure, lack of a sense of community, and social influence are the potential 
reasons why learners are not satisfied [30-32] with the assessment of learning that remains one of the main challenges [33].

Of course, distance learning has changed the role of teachers in the traditional learning system [34] and their relationship with learners. The main benefit is represented by a greater flexibility in terms of access to learning resources [35], but the instrumentalization of educational activities is left to the students themselves, rather than to an expert figure, and they are not always capable of structuring their learning path.

In the struggle for competition and international visibility, distance learning can be seen as a great opportunity for higher education institutions, in order to strengthen their brand and to widen the supply for their students.

Thus, learning is not merely the transfer of knowledge from teacher to learner in a single environment, but it derives from the transformation and the transfer of knowledge through the interaction of people, both online and offline [36].

Generally, distance learning has developed to fulfill additional needs, but in a time when students are expecting to learn and to be taught through methods in accordance with their personal preferences (implementing modern technologies) [37], universities, especially the traditional ones, have to look at online courses in order to develop their new digital strategy in a quick and effective way [38]. However, to achieve successful digital transformation, higher education institutions have to be digitally well-equipped, and students, staff, and academics have to be prepared to study, work, and teach with digital devices and techniques, driving innovation and disruption approaches [39].

Distance learning represents a complex field, and there is no unified understanding of how to plan, practice, and evaluate it, but different national and scientific traditions of educational science and philosophy can influence its development. According to Bates [40], distance learning is a broader concept, including online learning and remote learning. According to Bozkurt et al. [8], another branch of distance learning is represented by emergency remote education, which can be defined as way of "surviving in a time of crisis with all resources available, including offline and/or online resources" [7]. It is clear that, while distance learning represents an option, based on planning, theoretical and practical competences, and consolidated models, emergency remote education is the need of changing to react in an emergency time.

Of course, several education systems more used to facing challenges, learning, and evolving themselves would be more ready to welcome and develop distance formats, while other systems, still focused on their bureaucratic and static structures, could appear more reluctant to do it. Today, academic institutions have to continually update and advance their management and learning processes, fostering connectivity among students, staff, and departments. Digital approaches require skills, knowledge, and confidence to use new technologies, but not all universities and faculty members are ready to welcome such changes: so far, the Italian higher education system has never distinguished itself for its capacity to innovate and evolve, characterized by top down approaches and a limited autonomy [41]. Consequently, poor attention has been dedicated to the potential of distance learning and its development in the national context.

With the Covid-19 outbreak, education systems have been forced to move to online platforms, with the aim to ensure continuity in education and training paths. More in depth, they have been forced to develop and improvise blended solutions, combining elements coming from online and remote learning: if they had to completely translate their activity online, they did not have time to plan and organize it.

As anticipated by Cleveland-Innes and Lim [42,43], tutor/learner-readiness is regarded as the main risk connected to the development of distance learning: of course, it has represented the main difficulty faced by the Italian education system, effectively surpassed after an initial phase of uncertainty.

Distance learning, previously perceived as "optional", has been adopted as the only means to provide education, highlighting a lack of flexibility, resources, and competences for many institutions. In this sense, three different assets emerged as crucial in order to 
achieve success in such a new experience: a clear and strong leadership, able to assume relevant decisions even in crisis situations; effective communication to better engage stakeholders (internal and external); and concrete support provided by administrative staff, ensuring continuity for what concerns new settings and formats [44].

Covid-19 changed the lifestyle for citizens all over the world, generating a considerable number of deaths and unquantifiable damages in social and economic terms, but the resilience capacity of systems can reduce such damages [9], with knowledge that maintains its leading role in the provision of opportunities to face the emergency.

Covid-19 can be seen as the beginning of a new era for higher education and distance learning; especially for those systems, like the Italian one, that are shy in opening themselves to the exploitation of new technologies, it can be seen as an opportunity to change and to evolve. Nevertheless, digitalization for the university has to be seen not as a purpose per se, but it helps in order to make universities' products and services better, also from a sustainable perspective, but there are aspects, such as face-to-face meetings, working in groups, and learning from each other, that have to stay.

\section{Research Methodology}

As already declared, the aim of the paper is to investigate the strategic model of distance learning characterizing higher education in Italy, showing the effects generated by the diffusion of the health emergency. More precisely, the aim is to identify specific best practices that, even after the end of the emergency, can be adopted by all Italian higher education institutions in order to boost their digital supply and compete in an international context, evolving distance learning from emergency remote learning to a usual and structured practice within universities.

\section{Research Design}

After a theoretical background on the digitalization of higher education, aimed at pointing out benefits and risks connected with the development of distance learning, in order to achieve the scope previously mentioned, the method of case study will be adopted. Generally, the term "case" refers to a specific location, community, or organization; in this sense, the Italian higher education system will be the object of the research, representing an exemplifying case [45]. It has been chosen not because it is extreme or unusual, but because it epitomizes a broader category of cases, allowing the researchers to examine such key progress. In this sense, the Italian case is apt to generate new theory out of the findings, allowing the observation of the evolution of distance learning within higher education institutions: if during the health emergency it has been adopted in the form of emergency remote education, we expect it to become a more usual and structured practice, enabling the development of green campuses [11,12]. As suggested by Bryman [46], researchers are members of the system analyzed, so they can provide additional longitudinal elements.

The Italian higher education system represents the starting point of this analysis; it is composed of 98 higher education institutions and, among these, 67 are state universities, while 31 are non-state universities. The term "non-state" does not mean "private": indeed, among the 31 non-state universities, eight do not belong to the State, but to other public entities, while the other 23 are effectively "private". Among state universities, three are technical universities, completely focused on engineering and architecture; six are schools for advanced studies, specialized in postgraduate studies; and two are for foreigners, aiming to foster the advancement and dissemination of the Italian language, culture, and literature.

Among non-state institutions, three are characterized by a religious orientation; 11 are online universities, specialized in e-learning and distance programs; and only one, the University for Foreigners Dante Alighieri, is dedicated to foreign students.

On the basis of the number of students, there are 12 large universities, with more than 40,000 students; 29 middle universities, with a number of students between 15,000 and 40,000; and 56 small universities, with less than 15,000 students. The system enrolls about 
$1,700,000$ students; $90 \%$ of them attend state institutions, with only $10 \%$ attending non state ones, and among them, only $3.5 \%$ are enrolled in online universities [47].

The study will be structured in two main parts: the first one aims to provide a general view about distance learning in the national context before the pandemic, considering all the Italian higher education institutions, while the second one is exclusively focused on the behavior adopted by traditional higher education institutions (basically less used to operate online) during the health emergency, taking into account all the legislative measures enacted by the Italian government. Therefore, for what concerns the second part of the study, the sample will be composed of only 87 universities, excluding the online ones.

Data were collected by taking into account official statements provided by the Italian National Agency for the Evaluation of the University and Research Systems (ANVUR) and by institutions investigated. The process was not easy, since not all universities publicly share their digital strategy, communicating with students by mails, even during the pandemic. In this sense, the initial strategy was to look at universities' official websites in order to find specific sections dedicated to the pandemic outbreak and the strategy to face it, but then, given the lack of data, every form of communication about digital strategy was taken into account. Then, data were analyzed qualitatively: for what concerns the second phase of the study, they were organized in an excel file, aimed to highlight the number and the type of online platforms used by each institution to provide education. The aim was to understand how different platforms can be combined in order to enhance the quality of services provided.

Through a more in-depth analysis, based on the official measures enacted by universities' rectors, the effort was to understand the future of the Italian distance learning, answering these research questions: how has Italian higher education reacted to Covid19 outbreak? Which lessons can be learned from the pandemic experience? At the end, findings were presented with the aim to provide answers to such questions.

\section{Findings}

The following section is divided in two different paragraphs. Paragraph 4.1 will present the situation of distance learning in Italy before the health emergency, taking into account the entire higher education system (composed of traditional and online institutions). Then, paragraph 4.2 aims to show changes that have occurred in universities' behavior in response to the health emergency. After a brief resume of the measures enacted to regulate education during the emergency, it will be focused exclusively on traditional universities, pointing out their new e-learning strategy, in order to individuate a new distance learning model (on the basis of the best practices) for the future of the Italian university system.

\subsection{The Italian Distance Learning before the Covid-19 Outbreak}

By referring to the period before the health emergency, in a context where all higher education institutions over the world have started to think and to apply more sustainable learning experiences, exploiting technology, the Italian system turned out to be still concentrated on restrictive bureaucratic regulations.

In this sense, if compared to the international scenario, Italy showed a large delay (more or less 15 years) [48]. Of course, the delay was due to the poor autonomy that has characterized the Italian higher education system during the last years, with universities that started to think about their specific strategic plan only in 2009 [49], but then there were other two specific causes. The first one regarded a negative perception about the introduction of technology in education: new devices were considered dangerous, generating alienation in the traditional teaching relationship. The other one derived from the habit of associating online courses with private online universities, perceived as providers of a lower quality education. Indeed, based on the provision of virtual exams and a weak assessment process for what concerns students' progress, these institutions are able to ensure the achievement of degrees in exchange of large payments. 
Nevertheless, digital innovation has become a need and has started to spread through Italian universities, even despite the opinions of the education system leadership and people's traditional aversions.

Students have started to use the web as a support to traditional lectures: they downloaded teaching materials recommended or created by professors or looked for further information in order to know more about a specific topic of the course or a specific area of interest. On the other hand, professors have started to require their students to produce digital documents.

In this sense, the weight of distance learning has grown from $2.3 \%$ to $4.2 \%$ in ten years: while in 2011, 100 courses were provided online, in 2019, they became 195. Of course, most (about 60\%) distance learning initiatives belonged to online universities, with traditional ones that started to open themselves to new technologies (the University of Turin provided eight online degree paths, the University of Foggia and the University of Rome Tor Vergata had seven). At the same time, beyond the 11 online universities, no traditional institution communicated to diversify its supply through distance learning solutions. They preferred to share and advertise the quality of their activities for what concerns teaching, research, and, sometimes, social engagement, increasing traditional people's conviction about their superiority over online universities.

In this sense, in Italy, the digital revolution in the education system had started, but it appeared in a preliminary stage, characterized by a bottom up path and based on the adoption of non-institutionalized good practices that just aimed to support traditional courses, rarely to replace them. A relevant attempt through which traditional Italian higher education institutions tried to react to the changes occurred in the education market was represented by a design and delivery platform founded by 17 public Italian universities (Aldo Moro University of Bari, Polytechnic of Bari, Bolzano, Catania, Ferrara, Foggia, Genova, LUMSA, Marche, Milano-Bicocca, Modena and Reggio Emilia, Padova, Parma, Perugia, University of Salento, Salerno, and Ca' Foscari University) and aimed to offer distance learning courses for all (students, workers, and citizens who want to learn); it was financed by the Ministry of Education.

On the basis of this evidence, for what concerns the Italian higher education before Covid-19 outbreak, it was characterized by the lack of specific regulations defining the provision of distance learning, its attractiveness, its effectiveness, and its composition of digital resources [50].

\subsection{Higher Education's Response to Covid-19 Outbreak}

During the health emergency, a series of legislative measures has been enacted in order to re-organize the Italian education system. The aim has always been to ensure public health protection and, at the same time, the right to study for all.

The first measure was enacted on 23 February 2020, addressed to all the education institutions (including universities) located in the most affected regions by the virus (Emilia Romagna, Lombardia, and Veneto) and consisting in mere advice to suspend teaching activities, soliciting the autonomy of every institution. A more effective measure was represented by the DPCM (President of the Council of Ministers' decree) enacted on the 1 March 2020, according to which every education institution (for all levels) was obliged to suspend its activity, even referring to the most affected regions.

Through the following DPCM, enacted on 4 March 2020, the previous measures were extended to the national territory, so every education institution in Italy had to suspend its teaching activity, providing distance learning solutions. In this context, universities, by observing security measures, could develop their research activity. The following DPCMs and law decrees were enacted with the aim to extend the suspension of teaching.

Then, further measures were enacted, and while on May 4 the aim was to present indications for what concerns the "second and third" phase of lockdown, ensuring safety for all and continuity for what concerns universities' activity (education programs, research activity, and assistance for local needs), the decree of May 13 was about the provision of 
62 million euros in order to bridge the digital gap and to evenly facilitate the access to distance learning for students. On May 17, instead, the suspension of teaching activities and the need to develop distance learning solutions was confirmed for every education system.

At the end, the Government left to every institution the autonomy to organize written tests and graduations in presence in July, stimulating confusion among academic communities.

After the end of the summer, universities tried to re-start, providing blended learning solutions, especially for what concerns students of the first year, in order to better introduce them to the education path, but the diffusion of the second wave of the virus forced the Government to enact further DPCMs (on 18 and 24 October 2020). Through such measures, higher education institutions were invited to adopt distance learning and smart working solutions, reducing the contagion risk.

Therefore, in this context, traditional universities have been called to define the way to operate until the end of the emergency, on the basis of their decision-making autonomy.

In the sample, composed of 87 traditional universities (excluding the online ones), 15 do not share the number and the type of online platforms used, and one of them communicates to students exclusively through emails.

Then, 38 universities have decided to exploit only one online platform to provide education and perform exams and graduation exams; 26 have adopted two different platforms (generally one for teaching and oral exams and another one for written tests); six institutions have implemented three online platforms; only one institution, the Sapienza University of Rome, has used four online platforms; and another one, the University of Milan "Statale", has adopted six different platforms. Focusing on this institution, every platform is aimed to a specific activity: Microsoft Teams and Zoom are used to provide lessons and for oral exams, Moodle SEB and exam.net are dedicated to written exams, Proctoring to propose quiz, and UNIMIA to written exams on paper. Furthermore, this institution is the only one to provide an "Ariel Plan" to help professors with distance instruments, without saying anything about its future distance learning.

Generally, Microsoft Teams seems the most exploited; it has been adopted by 36 institutions, even if 22 of them have decided to accompany Teams with another platform, especially for what concerns written exams, while nine institutions have decided to use their own e-learning platforms (two of them combine them with another).

Moodle has been chosen by 20 institutions, but for most of them it represents a support to perform written exams; for five universities it is the only platform exploited.

As previously mentioned, every institution has been called to organize its activity independently during the following phases of the emergency, so rectors have started to enact temporary measures.

Thirty-nine Italian universities do not communicate their arrangements on their websites, for 17 of them there is no arrangement enacted by rector on the website (probably they use other communication means), while the others 22 just communicate to operate online, without specifying further information about time: some of them declare to continue until new alerts, others until the end of the emergency.

Thirty-two higher education institutions specify to adopt distance learning until the end of the academic year, even if with different deadlines.

Nine universities appeared braver, having anticipated the end of the measures enacted in late May or in June; only the University of Trieste declared to operate in distance until the end of July, but to experiment blended opportunities for exams and graduations starting from June 15. Only five universities communicated to exploit distance learning even during the first semester 2020/2021, and only one university, the University of Genoa, explicitly declared the intention to maintain its identity as a traditional university. With the spread of the second wave, a time of uncertainty was opened for Italian higher education institutions: they translated again to their distance learning, except for medical disciplines, without specifying which will be the duration of the measure, strictly related to the trend of the 
pandemic emergency and to the need to ensure public health for their students, of course, even with the hope to come back to a "normal life" as soon as possible.

\section{Discussion}

In a knowledge-based society, globalization and the spread of internet and other technology devices have encouraged the need for new learning formats [6] and the diffusion of digitalization, also in higher education. Distance learning is seen as an evolution of lifelong learning, through the appearance of online universities and several forms of elearning and blended learning. Distance learning could help universities in their transition from closed education systems to mass ones, ensuring open access, open education, open teaching, and network participation, but, at the same time, it could represent a risk for what concerns the quality of education and the possibility to lose customers (students) during their educational path. Especially through its configuration of emergency remote education, distance learning can help in responding to an emergency, allowing continuity in education programs.

The Italian context, previously characterized by a negative perception about technological devices in education processes and the quality of education provided by online universities, has been always characterized by a large delay in terms of education digitalization [48] if compared with the international scenario. Starting from such a delay, it has represented the object of this work.

Digitalization enabled new opportunities in every field, also in higher education, increasing interactions and collaborations with stakeholders [26], but also the possibility to create value in a new, circular, and sustainable way [11]. Nevertheless, not all higher education institutions have welcomed such processes [1] and while some of them decided to find their identity on the exploitation of digital devices (online universities), others shared doubts on the introduction of technology in higher education.

In a time when the emergency has not yet ended, on the basis of these considerations, the study underlines how the pandemic has forced the Italian higher education to evolve and to experiment with a new strategic behavior. Comparing two different situations, the situation before Covid-19 outbreak and that characterized by the need to face it, the aim was to observe and describe the resilience of the Italian education system. More precisely, the focus was on the strategy of emergency remote education adopted by universities, hypothesizing how the future of the Italian higher education could be (with distance learning that will probably become a usual and structured practice).

Indeed, after the first and timid attempts to exploit technologies in education performed by Italian universities, it is during the pandemic crisis that distance learning has been used as emergency remote education and has been transformed from a support for traditional means to the only instrument to ensure continuity in education and, at the same time, public health protection for all.

Of course, it brings a series of disadvantages, represented by the risk students or points in education quality [27], confirming the value of real interactions and the need, for universities, to remain a place of sociality and growth for students.

The Italian university case was investigated through a documentary analysis, looking at what universities communicate in their official websites and documents. The data collection process was not easy, characterized by fragmentation for what concerns information shared by every institution and a multitude of measures enacted by the Italian government to regulate the necessary lockdown, firstly addressed to the most affected regions and then extended to all the national territory. In this sense, the most relevant decrees have been the DPCM enacted on 4 March 2020, through which every education institution stopped its teaching activity and started to provide distance learning solutions, and the last ones, enacted in October 2020, through which distance learning has been highly recommended and traditional universities have been called to define the way to operate up to the end of the emergency, on the basis of their decision-making autonomy. 
Every Italian university has dedicated a temporary space on its website to Covid-19, some of them just to remind readers of good and hygienic practices, others to offer updates on the virus trend, and others to share the rector's decisions with their academic community.

In this sense, for 15 universities, it has not been possible to analyze the distance learning platform used; 17 universities do not share their rector's decision, and another 22 declare to operate online, without offering further and more precise indications.

Looking at available information, research findings demonstrate the resilience capacity of the Italian higher education system, able to react and to evolve, re-organizing itself in only one week.

Indeed, while before the pandemic the Italian university system registered only timid attempts to become more digital, looking at distance solutions as a mere support to traditional learning and teaching tools, it is during the emergency that distance learning has become the only means able to ensure the right to study and health protection for all. It is on the basis of such evolution observed that we believe in a new era for higher education, characterized by a structured use of digital devices and, consequently, more attention to sustainable approaches [11,12].

The main risk connected to the pandemic is to register a drop in the number of university students, and to avoid it, the Ministry of the University ensures the right to study for all through three main measures: reduction on fees, increase in scholarships, and incentives to face the digital divide.

Exams, especially written tests, and graduations continue to represent hard proofs for universities: mutual trust is needed, because if institutions have to respect students' privacy, on the other hand students must be serious.

\section{Preliminary Conclusions}

Distance learning has been an important solution, an effective answer to an unpredictable situation, but universities have always been a place of meeting for students, and the intention is to come back to normality as soon as possible, considering distance learning as a support instrument to manage off-site and foreign students, performing blended learning opportunities, and enabling the idea of green campuses. Of course, thanks to emergency remote education, the Italian university system has never stopped its activity, and students have continued to take exams and to graduate, but looking at the future, it does not intend to change its peculiarity.

Distance learning has been a challenge for students not used to learning in an online environment, but also for teachers, taking time and preparation to quickly adapt traditional and in presence lectures to a virtual format. In this sense, the University of Milan "Statale" can be seen as a good example, performing an ad hoc program to sustain professors in this drastic transition. This institution is at the forefront even for what concerns the organization of distance teaching: it exploits six different platforms, with the aim to ensure the best in all aspects.

Of course, each institution has developed its distance learning strategy in its own way, but in general, Italian higher education has demonstrated how resilience is needed in order to react, ensuring continuity for its teaching and research activity.

The practical implications are related to the potential of technology, presented as a crucial instrument in a time of crisis, when social distance has become the golden rule, but also for the future, ensuring new and sustainable ways to create value [12].

Looking at lessons learned from the pandemic experience, three different dimensions appeared as fundamental for distance learning [44]; they are represented first of all by a clear and strong leadership, able to transmit a sense of management for the entire situation; effective communication, in order to engage with a larger audience and to share a sense of belonging to a specific community; and then administrative support in order to ensure continuity for what concerns distance services.

If the paper was dedicated to the first phase of the emergency, in a future perspective, the aim would be to compare the Italian case in the international context, individuating 
the impact generated by different models of distance education, that will be considered as ordinary practices and not as extraordinary ones.

The results of the pandemic may be a stronger university, aware of digital potential and the relevance of distance instruments, but even a physical community; maybe it will be a new university, halfway between a traditional and an online one. In this sense, the pandemic has represented the beginning of a new era for Italian universities: it has demonstrated that technological devices and distance learning represent a way to do more and not less, fostering a new sustainable sensitivity, because if the knowledge is the key to success, universities must be the place to re-start from.

Author Contributions: Conceptualization: R.F. and C.F.; methodology: N.C.; validation: A.A., G.F., N.C., and R.F.; formal analysis: C.F.; investigation: C.F. and R.F.; resources: R.F.; data curation: C.F.; writing-original draft preparation: C.F.; writing-review and editing: C.F., N.C, R.F., and A.A.; supervision: A.A. and G.F. All authors have read and agreed to the published version of the manuscript.

Funding: This research was supported and funded by the University of Rome Tor Vergata, Department of Management and Law by the research project named "Sustainable Development" and by the "MARIS" Master Program in "Reporting Innovation Sustainability".

Institutional Review Board Statement: Not Applicable.

Informed Consent Statement: Not Applicable.

Data Availability Statement: Not Applicable.

Conflicts of Interest: The authors declare that they have no conflict of interest.

\section{References}

1. Kooskora, M. The Role of an Entrepreneurial Mindset in Digital Transformation-Case Study of the Estonian Business School. In Digital Entrepreneurship: Impact on Business and Society; Soltanifar, M., Hughes, M., Gocke, L., Eds.; Springer: Cham, Switzerland, 2021; pp. 143-164.

2. Westerman, G.; Bonnet, D.; McAfee, A. Leading Digital: Tuning Technology into Business Transformation; Harvard Business Review: Brighton, MA, USA, 2014.

3. Drucker, P.F. Post-Capitalist Society; Harper Bus: New York, NY, USA, 1993.

4. Boucouvalas, A. Self-Directed Learning: Critical Practice; Routledge: Abingdon, UK, 1981.

5. Jarvis, P. Adult Education and Lifelong Learning: Theory and Practice; Routledge: Abingdon, UK, 1986.

6. Dan, M.C. The Third Mission of Universities in the Development Strategy of Vienna City. Inform. Econ. 2012, 16, 49-56.

7. Giacosa, A. Can Emergency Remote Education Make our Universities "Smarter"? Some Reflections Based on Students" Perceptions. In Proceedings of the DIDAMATiCA 2020: “Smarter School for SmartCities", Trieste, Italy, 6-8 May 2020. Available online: https://www.researchgate.net/publication/346038670_Can_Emergency_Remote_Education_make_our_ universities_smarter_Some_reflections_based_on_students $\backslash$ T1 $\backslash$ textquoteright_perceptions (accessed on 10 July 2020).

8. Bozkurt, A.; Xiao, F.; Jung, I.; Vladimirshi, V. A global outlook to the interruption of education due to COVID-19 Pandemic: Navigating in a time of uncertainty and crisis. Asian J. Distance Educ. 2020, 15, 1-126.

9. D'Adamo, I.; Rosa, P. How Do You See Infrastructure? Green Energy to Provide Economic Growth after COVID-19. Sustainability 2020, 12, 4387.

10. Gallagher, V.C.; Hrivnak, M.W.; Valcea, S.; Mahoney, C.B.; LaWong, D. A comprehensive three- dimensional sustainability measure: The 'missing $\mathrm{P}^{\prime}$ of 'people' - A vital stakeholder in sustainable development. Corp. So Responsib. Environ. Manag. 2018, 25, 772-787. [CrossRef]

11. Sonetti, G.; Lombardi, P.; Chelleri, L. True Green and Sustainable University Campuses? Toward a Clusters Approach. Sustainability 2016, 8, 83. [CrossRef]

12. Tudorie, C.A.-M.; Vallés-Planells, M.; Gielen, E.; Arroyo, R.; Galiana, F. Towards a Greener University: Perceptions of Landscape Services in Campus Open Space. Sustainability 2020, 12, 6047.

13. Pagani, M. Digital business strategy and value creation: Framing the dynamic cycle of control points. MIS Q. 2013, 37, 617-632. [CrossRef]

14. Gronroos, M.G. Mahdollisuuden Aika kohti Virtuaalista Organisaatiota; Tammer-Paino Oy: Tampere, Finland, 2006.

15. Zaborova, E.N.; Glazkova, I.G.; Markova, T.L. Distance learning: Students' perspective. Sociol. Stud. $2017,2,131-139$.

16. PwC. The 2018 University-Making the Right Choices, Making It Happen. 2015. Available online: https://www.pwc.com/mx/ es/publicaciones/c2g/231_2018-university-making-the-right-choices-making-it-happen.pdf (accessed on 23 June 2020).

17. MicKinsey. A Labour Market that Works: Connecting Talent with Opportunity in the Digital Age; McKinsey Global Institute: New York, NY, USA, 2015. 
18. Etzkowitz, H. The norms of entrepreneurial science: Cognitive effects of the new university-industry linkages. Res. Policy 1998, 27, 823-833. [CrossRef]

19. Jokhan, A.; Sharma, B.; Singh, S. Early warning system as a predictor for student performance in higher education blended courses. Stud. High. Educ. 2018, 44, 1900-1911. [CrossRef]

20. Darkenwald, G.G.; Merriam, S.B. Adult Education: Foundations of Practice; Harper and Row: New York, NY, USA, 1982.

21. Derounian, J.G. Active Learning in Higher Education. SAGE J. 2017, 13, 9-21.

22. Kaplan, A.M.; Haenlein, M. Higher education and the digital revolution: About MOOCs, SPOCs, social media, and the Cookie Monster. Bus. Horiz. 2016, 59, 441-450. [CrossRef]

23. Gottschalk, T. Print tools in distance education. In Distance Education: Strategies and Tools; Wills, B., Ed.; Educational Technology Publications: Englewood Cliffs, NJ, USA, 1994.

24. Buhl, M.; Andreasen, L.B. Learning potentials and educational challenges of massive open online courses (MOOCs) in lifelong learning. Int. Rev. Educ. 2018, 64, 151-160. [CrossRef]

25. Ilmarinem, V.; Koskela, K. Digitalisaatio; Talentum: Helsinki, Finland, 2015.

26. Berman, S.J. Digital transformation: Opportunities to create new business models. Strategy Leadersh. 2012, 40, 16-24. [CrossRef]

27. Matzler, K.; Strobl, A.; Thurner, N.; Fuller, J. Switching experience, customer satisfaction and switching costs in the ICT industry. J. Serv. Manag. 2015, 26, 117-136. [CrossRef]

28. Bentley, P.J. Digitized; Oxford University Press: New York, NY, USA, 2012.

29. Veletsianos, G.; Kimmons, R. Assumption and challenges of open scholarship. Int. Rev. Res. Open Distance Learn. 2012, 13, 166-189.

30. Hone, K.S.; El Said, G.R. Exploring the factors affecting MOOC retention: A survey study. Comput. Educ. 2016, 98, 157-168. [CrossRef]

31. Zheng, S.; Rosson, M.B.; Shih, P.C.; Carroll, J.M. Understanding student motivation, behaviours and perceptions in MOOCs. In Proceedings of the 18th ACM Conference on Computer Supported Cooperative Work \& Social Computing, Vancouver, BC, Canada, 14-18 March 2015; pp. 1882-1895.

32. Singh, A.B. Learning through Massive Open Online Courses (MOOCs): A Case of the First International MOO Offered by University of Oslo in 2015. Master's Thesis, Department of Education, University of Oslo, Oslo, Norway, 2016.

33. Xiong, Y.; Suen, H.K. Assessment approaches in massive open online courses: Possibilities, challenges and future directions. Int. Rev. Educ. 2018, 64, 241-263. [CrossRef]

34. Dale, E.L. Pedagogisk Profesjionalitet [Pedagogical Professionalism]; Gyldendal: Oslo, Norway, 1989.

35. Buhl, M.; Andreasen, L.B. MOOCs-The promise of meeting the need of flexibility for the adult learner? In Proceedings of the 15th European Conference on e-Learning, Prague, Czech Republic, 27-28 October 2016; Novotna, J., Jarcarik, A., Eds.; Academic Conferences and Publishing International Limited: Reading, UK, 2016; pp. 98-104.

36. Kop, R. The challenges to connectivist learning on open online networks: Learning experiences during a massive open online course. Int. Rev. Res. Open Distrib. Learn. 2011, 12, 19-38.

37. Kirkwood, A.; Price, L. Examining some assumptions and limitations of research on the effects of emerging technologies for teaching and learning in higher education. Br. J. Educ. Technol. 2013, 44, 536-543.

38. Berger, T.; Frey, B. Digitalisation, Jobs and Convergence in Europe: Strategies for Closing the Skills Gap; Oxford Martin School: Oxford, UK, 2016.

39. Khalid, J.; Ram, B.R.; Soliman, M.; Ali, A.J.; Khaleel, M.; Islam, M.S. Promising digital university: A pivotal need for higher education transformation. Int. J. Manag. Educ. 2018, 12, 264-275. [CrossRef]

40. Bates, A. Teaching in a Digital Age, 2nd ed. 2019. Available online: https://pressbooks.bccampus.ca/teachinginadigitalagev2/ (accessed on 23 June 2020).

41. Vaira, M. La Costruzione Della Riforma Universitaria e Dell'autonomia Didattica: Idee, Norme, Pratiche, Attori; LED Edizioni Universitarie: Milano, Italy, 2011.

42. Cleveland-Innes, M. Teaching in an online community of inquiry: Institutional and individual adjustment in the new higher education. In Educational Communities of Inquiry: Theoretical Framework, Research and Practice; Akyol, Z., Garrison, R., Eds.; IGI Global: Hershey, PA, USA, 2013.

43. Lim, C. Cultivating higher order thinking dispositions in undergraduate students. Int. J. Learn. Teach. 2017, 3, 154-159. [CrossRef]

44. Agasisti, T.; Soncin, M. Higher education in troubled times: On the impact of Covid-19 in Italy. Stud. High. Educ. 2020, 46, 86-95. [CrossRef]

45. Yin, R.K. Case Study Research: Design and Methods, 4th ed.; Sage: Los Angeles, CA, USA, 2009.

46. Bryman, A. Social Research Methods; University Press: Oxford, UK, 2012.

47. ANVUR. Rapporto Biennale Sullo Stato del Sistema Universitario e Della Ricercar; ANVUR: Roma, Italy, 2018.

48. OECD. Review of the Italian Strategy for Digital Schools; OECD Publishing: Paris, France, 2013.

49. Giusepponi, K.; Tavoletti, E. Vision and Mission Statements in Italian Universities: Results of an Empirical Investigation on Strategic Orientation. J. Knowl. Econ. 2015, 9, 301-328. [CrossRef]

50. Walker, L.; Loch, B. Academics' perceptions on the quality of MOOCs: An empirical study. Int. J. Innov. Qual. Learn. 2014, 22, 53-63. 